\title{
Coronavirus: doctor who faced backlash from police after warning of outbreak dies
}

\author{
Elisabeth Mahase
}

The BMJ

Li Wenliang-a doctor from Wuhan, China, who said he was reprimanded by police for warning other doctors about novel coronavirus at the start of the outbreak-has died after being infected with 2019-nCoV.

When the first cases of a pneumonia-like condition appeared in a local hospital, Li sent messages to his medical school alumni group on the Chinese messaging app WeChat, warning that, from the test results he had seen, it appeared to be a coronavirus. Coronaviruses are a family of viruses that includes severe acute respiratory syndrome (SARS).

In an interview with the US news outlet CNN before he died, Li said that he was trying to remind his friends to be careful, but after the screenshots of his messages (sent 30 December 2019) had gone viral online, he was called in by local police and reprimanded for spreading rumours and disrupting social order.

Li said he was made to sign a statement admitting his misdemeanour and promising not to commit further unlawful acts. This happened on the same day that Wuhan authorities announced the outbreak and alerted the World Health Organization. ${ }^{1}$

Li became ill after treating a patient with undiagnosed 2019-nCoV and was confirmed to have the virus himself on 2 February. He reportedly died on 7 February.
Responding to the news of his death during a briefing about the outbreak on 6 February, executive director of the WHO health emergencies programme, Mike Ryan, said, "We are deeply saddened by the passing of Li Wenliang. We all need to celebrate the work that he did on novel coronavirus."

As of 6 February, the Chinese National Health Commission has reported 28018 confirmed cases, including 3859 in a serious condition and 563 deaths. It said 1153 patients have recovered and have been discharged from hospital. There are an additional 24702 suspected cases. Meanwhile, in Hong Kong there are 21 confirmed cases and one death, while in Macao and Taiwan there are 10 and 11 cases respectively. ${ }^{2}$

Outside China, 225 cases and one death have been confirmed in 24 countries.

Correction: Li Wenliang was reported to have died on 7 February, not 6 February as originally stated in this story.

Xiong Y, Gan N. This Chinese doctor tried to save lives, but was silenced. Now he has coronavirus. CNN. 4 February 4 2020. https://edition.cnn.com/2020/02/03/asia/coronavirusdoctor-whistle-blower-intl-hnk/index.html.

2 Chinese National Health Commission. Feb 6: daily briefing on novel coronavirus cases in China. 6 February 2020. http://en.nhc.gov.cn/2020-02/06/c_76264.htm

Published by the BMJ Publishing Group Limited. For permission to use (where not already granted under a licence) please go to http://group.bmj.com/group/rights-licensing/ permissions 